К. С. Васюта, Д. А. Чопенко, Н. В. Гармаш

Харківський національний університет Повітряних Сил імені Івана Кожедуба, Харків, Україна

\title{
МЕТОД СИНТЕЗУ ВАРІАНТІВ РІШЕНЬ У ВІДКРИТІЙ ЕКСПЕРТНІЙ СИСТЕМІ ПУНКТУ УПРАВЛІННЯ ПОВІТРЯНИХ СИЛ 3 УРАХУВАННЯМ РЕСУРСНО-ЧАСОВИХ ОБМЕЖЕНЬ
}

\begin{abstract}
Анотація. Предметом вивчення в статті є синтез можливих варіантів досягнення рішень з урахуванням заданих ресурсно-часових обмежень у відкритій експертній системі пункту управління Повітряних Сил. Метою $є$ розробка методу синтезу варіантів рішень у відкритій експертній системі пункту управління Повітряних Сил з врахуванням ресурсно-часових обмежень. Проведений аналіз можливості досягнення множини цільових станів по ресурсам $\mathrm{i}$ часу на стрічковій діаграмі Ганта та методами мережного планування та управління. Отримані такі результати. Описані етапи синтезу можливих варіантів, особливості представлення варіанту досягнення цілей. Сформульована задача аналізу реалізуємості варіантів досягнення цілей. Наведений приклад фрагменту графу варіанту досягнення цілей, що відображає процес вирішення задачі у відкритій експертній системі на пункті управління Повітряних Сил. Описаний метод аналізу реалізуємості варіанту досягнення цілей по ресурсам і часу. Запропонована побудова плану реалізації варіанту досягнення цілей. Розглянуто метод, що дозволяє синтезувати нездійсненні плани реалізації. Висновки. Розроблений метод синтезу можливих варіантів рішень дозволяє сформувати в реальному масштабі часу для кожного варіанту розвитку обстановки множину реалізуємих варіантів досягнення цілей (варіантів розподілу ресурсів), якщо вони існують. При цьому враховується той факт, що вихідні дані для розрахунків можуть бути задані як у вигляді точкових значень, так й у вигляді інтервалів можливих значень. Напрямком подальших досліджень є розробка методу коригування варіанту розвитку обстановки у випадку якщо в процесі вироблення рішень для певного виду розвитку обстановки не вдалося сформувати жодного реалізуємого варіанту досягнення цілей.
\end{abstract}

Ключ ов і слов : пункт управління, відкрита експертна система, ресурсно-часові обмеження, метод мережевого планування та управління, формалізація, структура цільових установок.

\section{Ветуп}

Постановка проблеми у загальному вигляді. Однією з основних задач відкритої експертної системи (ВЕС) пункту управління (ПУ) Повітряних Сил (ПС) $є$ аналіз обстановки, що склалася, синтез та видача на затвердження командиру можливих варіантів розподілу підпорядкованих сил і засобів по об'єктам впливів, які необхідно здійснити для виконання поставленого завдання, тобто досягнення актуальних цілей управління [1].

При побудові можливих варіантів рішень потрібно враховувати не тільки можливість досягнення актуальних цілей виходячи зі структури узагальненої мережної моделі, а й існуючі обмеження ресурсу та часу виконання завдання ПУ [2]. Це обумовлено тим, що система має обмежений запас впливів кожного типу ресурсу. Тому необхідна розробка відповідного методу, який дозволяє не тільки побудувати можливі шляхи досягнення необхідних цільових станів, а й здійснити аналіз можливості їх реалізації $з$ урахуванням ресурсно-часових обмежень.

Мета статті - розробка методу синтезу варіантів рішень у відкритій експертній системі пункту управління Повітряних Сил 3 урахуванням ресурсно-часових обмежень.

Аналіз останніх досліджень і публікацій. В рамках формально-логічного апарату структури цільових установок (СЦУ) синтезовані можливі шляхи досягнення актуальних цілей представляються у вигляді звичайних мережних моделей [1]. Цю особливість необхідно врахувати при виборі методу, який використовується для перевірки реалізуємості різних варіантів по ресурсам і часу. В даному випа- дку аналіз можливості досягнення множини цільових станів фактично зводиться до задачі розподілу обмеженого запасу ресурсів для деякої послідовності дій [3].

У роботах [4-6] запропоновано здійснювати аналіз можливості досягнення множини цільових станів по ресурсам і часу безпосередньо на стрічковій діаграмі Ганта. Однак, усі методи планування і управління, що засновані на використанні таких діаграм, мають ряд серйозних недоліків, які не дозволяють їх застосовувати для вирішення задач управління в системах реального часу. Найбільш істотними з них є наступні [6]:

1. Стрічкові діаграми, які використовуються, не відображають всієї складності процесів і не дозволяють уявити різні взаємозв'язки між окремими діями (роботами).

2. Невідповідність цих методів планування i управління різноманіттю розглянутих робіт призводить до збільшення часу реалізації варіанту рішення. Причому найчастіше це відбувається не тому, що встановлені терміни розраховані невірно, а через неузгодженість окремих робіт між собою.

3. Дані методи не враховують існуючу невизначеність, яка притаманна будь-якому реальному процесу управління бойовими діями.

4. Дуже обмежені можливості прогнозу виконання комплексу робіт, що ускладнює вибір правильного рішення при розподілі ресурсів системи.

5. Ці методи не дозволяють здійснювати оперативне коригування плану реалізації комплексу робіт.

Таким чином, методи, що засновані на стрічкових діаграмах неспроможні вирішувати задачі розподілу ресурсів в системах управління реального часу. 
В даний час для вирішення задач подібного класу найбільш добре розроблені методи мережного планування та управління (МПУ) $[7,8]$. Вони мають ряд переваг стосовно до розв'язуваної задачі.

Слід відзначити той факт, що до структури мережних моделей, які аналізуються методами МПУ, пред'являється ряд вимог [7]:

1) кожна дуга мережної моделі має певну орієнтацію;

2) в мережній моделі не повинно бути "тупикових" вершин (окрім кінцевих) і "висячих" вершин (окрім вихідних);

3) в мережній моделі не допускається наявність контурів і петель;

4) будь-які дві вершини повинні бути пов'язані не більш ніж однією дугою;

5) в мережній моделі не допускається імовірнісне розгалуження;

6) будь-яка робота не може початися поки не будуть закінчені усі попередні роботи (тобто мережна модель містить тільки вершини кон'юнктивного типу);

7) завжди можна так позначити кожну роботу, що іiї орієнтована дуга починається в вершині, яка має менший номер, ніж вершина, в якій вона закінчується.

У загальному випадку узагальнена мережна модель, що описує процес вирішення задач управління на ПУ ПС, не задовольняє повністю перерахованим вище вимогам, так як вона містить диз'юнктивні вершини і вершини типу розгалужувач (ймовірнісне розгалуження) [1]. Тому застосовувати методи МПУ можна лише для деякої частини узагальненої мережевої моделі, яка містить тільки кон'юнктивні вершини. Крім того, методам МПУ притаманні недоліки, які не дозволяють їх використовувати без доопрацювання для аналізу реалізуємості можливих варіантів рішень у відкритій експертній системі ПУ ПС [7].

Таким чином, методи МПУ можуть бути використані в ВЕС ПУ ПС для аналізу можливості досягнення актуальних цілей управління за ресурсами і часу (рішення задач розподілу обмежених ресурсів), з урахуванням їх відповідного доопрацювання.

\section{Основна частина}

У загальному випадку, виходячи 3 аналізу інформації, яка характеризує обстановку, що склалася і яка використовується особами бойової обслуги ПУ ПС для прийняття рішення неможливо однозначно визначити, як надалі буде розвиватися ситуація [8]. Це обумовлено як цілеспрямованою протидією противника, так і наявністю величезної кількості випадкових зовнішніх факторів. Тому необхідно синтезувати деяку множину різних варіантів розвитку обстановки, які характеризують послідовність дій системи в кожній конкретній ситуації.

При цьому під варіантами розвитку обстановки розуміються різні шляхи досягнення актуальних цілей даної системи управління, які обумовлені наявністю дій $з$ невизначеним результатом (тобто наявністю вершин-розгалужувачів в узагальненій ме- режній моделі). Мережна модель, яка відповідає варіанту розвитку обстановки, не містить в своєму складі вершин-розгалужувачів.

Загальна кількість варіантів розвитку обстановки в даному випадку обмежена і визначається кількістю і структурою вершин-розгалужувачів узагальненої мережної моделі [1].

Кожному варіанту розвитку обстановки відповідає деяка кінцева множина варіантів досягнення цілей. Фактично варіанти досягнення цілей обумовлені наявністю в узагальненій мережній моделі вершин диз'юнктивного типу $[9,10]$.

Варіант досягнення цілей характеризується планом реалізації (планом виконання робіт), який визначає послідовністю виконання дій (робіт) у часі, порядок і норми використання відповідних ресурсів. При цьому варіант досягнення цілей $є$ реалізуємим, якщо відповідний йому план реалізації задовольняє наступним умовам:

1. Чи дотримується послідовність, і терміни виконання робіт.

2. Чи не порушуються норми витрати ресурсів, які використовуються.

3. План реалізації варіанту досягнення цілей має певну кінцеву тривалість, що не перевищує встановленої величини $t_{m p}$.

Під можливим варіантом рішення розуміється один $з$ варіантів досягнення цілей, що реалізується за необхідними запасами ресурсів і часу.

Варіант розвитку обстановки вважається коректним (здійсненним), якщо в даній ситуації система володіє достатнім запасом ресурсів, які необхідні для досягнення цілей управління, i час досягнення поставлених цілей не перевищує встановленого граничного значення. Іншими словами варіант розвитку обстановки, коректний, якщо для нього можна сформувати, принаймні, один можливий варіант рішення.

Так як заздалегідь ми не можемо знати за яким варіантом надалі будуть розвиватися події, то поставлена задача буде вирішена повністю, якщо всі можливі варіанти розвитку обстановки є коректними. Якщо ж для будь-якого варіанту розвитку обстановки не вдалося сформувати варіант рішення, то необхідно виконати його коригування.

В системах управління реального часу однією 3 основних вимог є вимога до оперативності рішення, яке приймається [3]. Тому потрібно оцінити можливість вирішення поставленого завдання в повному обсязі в рамках встановленого часового інтервалу.

При цьому сумарний час, необхідний на синтез і аналіз усіх варіантів досягнення цілей, можна оцінити за формулою (1):

$$
t_{c y м}=\sum_{i=1}^{K в p o}\left(K в \partial u_{i} \times t_{c e p}\right),
$$

де Квро - кількість варіантів розвитку обстановки; $\kappa в д u_{i}-$ кількість можливих варіантів досягнення цілей в $i$-му варіанті розвитку обстановки; $t_{c e p}-$ середній час, необхідний на синтез і аналіз одного варіанту досягнення цілей. 
У загальному випадку, кількість варіантів розвитку обстановки визначається кількістю і структурою (кількістю альтернативних відносин) вершинрозгалужувачів і відповідно до цього може бути обчислена за наступною формулою (2):

$$
\text { Квро }=\prod_{g=1}^{G} \sum_{j=1}^{N в p_{g}}\left(d_{j}-m\right),
$$

де $G$ - кількість вихідних вершин-розгалужувачів. При цьому вважається, що розглянута вершина $є$ вихідною, якщо на шляху від множини початкових умов до цієї вершини немає ні однієї іншої вершини-розгалужувача; $N в p_{g}$ - сумарна кількість вершин-розгалужувачів, які знаходяться на шляху від $g$-ї вихідної вершини-розгалужувача до множини вершин, що мають максимальний рівень ієрархії (кінцевих вершин узагальненої мережної моделі); $d_{j}$ - кількість альтернативних відносин $j$-ї вершини-розгалужувача; $m$ - змінна, що приймає значення 0, якщо розглянута вершина-розгалужувач $є$ вихідною, та 1 в іншому випадку.

Аналогічно значення величини $K в д u_{i}$ визначається кількістю і структурою (кількістю вхідних дуг) диз'юнктивних вершин фрагменту мережної моделі, відповідного $i$-му варіанту розвитку обстановки, і обчислюється за формулою:

$$
\kappa в \partial u_{i}=\prod_{b=1}^{B} \sum_{s=1}^{N \partial \varepsilon_{b}}\left(h_{s}-l\right),
$$

де $B$ - кількість вихідних диз'юнктивних вершин. Вважається, що розглянута вершина $є$ вихідною, якщо на шляху від цієї вершини до множини кінцевих вершин узагальненої мережної моделі немає жодної іншої вершини диз'юнктивного типу; $N \partial b_{b}-$ сумарна кількість диз'юнктивних вершин, які знаходяться на шляху від $b$-ї вихідної вершини диз'юнктивного типу до множини вершин ПУ узагальненої мережевої моделі; $h_{s}-$ кількість дуг, які входять в $s$-ту диз'юнктивну вершину; $l$ - змінна аналогічна змінної $m$, тільки замість вершинрозгалужувачів аналізуються вершини диз'юнктивного типу.

Значення величини $t_{c e p}$ може бути визначено на етапі проектування і тестування ВЕС.

Синтез можливих варіантів рішень 3 урахуванням заданих ресурсно-часових обмежень повинен включати в себе наступні етапи:

1. Коригування узагальненої мережної моделі з урахуванням досягнутих ичільових станів в ситуації, щзо склалася в реальній дійсності.

Спершу здійснюється виявлення ситуації, яка склалася на даний момент часу в предметної області, шляхом аналізу множини означених початкових умов.

Після цього здійснюється усічення узагальненої мережної моделі виходячи з ситуації, що склалася [11]. Фактично на даному етапі виключаються 3 подальшого розгляду ЦУ, які є наслідком неозначених ПУ. Досягнуті цільові установки стають початковими умовами для цілей, досягнення яких можливо в майбутньому (облік властивості трансформації цілей).

2. Синтез можливих варіантів розвитку обстановки.

На даному етапі визначаються усі можливі варіанти розвитку обстановки, виходячи з нової структури узагальненої мережної моделі. Виділення усіх можливих варіантів розвитку обстановки на графі узагальненої мережної моделі доцільно проводити "знизу-вгору". Це обумовлено тим, що при такому підході найбільш просто виділити випадки альтернативного розгалуження графу з мінімальною кількістю проведених операцій. Так як наявність варіантів розвитку обстановки обумовлено тільки вершинами-розгалужувачами, то для виділення даних варіантів може бути використане наступне правило. Якщо під час руху по графу узагальненої мережної моделі "знизу-вгору" зустрічається вершина типу розгалужувач, то кількість варіантів розвитку обстановки буде дорівнювати кількості виходів розгалужувача, причому гілка, що знаходиться нижче розгалужувача, буде присутньою (буде загальною) в кожному з цих видів.

3. Аналіз можливості вирішення задачі в повному обсязі в рамках часового інтервалу, який відведений на прийняття рішення.

На даному етапі визначається можливість синтезу та аналізу усіх варіантів досягнення цілей в заданий проміжок часу. При цьому середній час аналізу $t_{c y м}$ усіх варіантів досягнення цілей можна оцінити відповідно до виразу (1). Якщо обчислене значення $t_{c y м}$ перевищує значення часу, яке відведене на прийняття рішення, то з подальшого розгляду виключається частина варіантів досягнення цілей.

4. Синтез та аналіз реалізуємості можливих варіантів досягнення иілей для усіх сформованих варіантів розвитку обстановки.

Синтез варіантів досягнення цілей здійснюється для кожного варіанту розвитку обстановки окремо. При цьому виділення усіх можливих шляхів досягнення цілей доцільно проводити "згори-вниз", в цьому випадку найбільш просто виділити випадки розгалуження деревовидного графу. Процедура виділення варіантів досягнення цілей на графі варіантів розвитку обстановки базується на наступному правилі. Якщо під час руху по графу "зверху-вниз" зустрічається вершина диз'юнктивного типу, то кількість варіантів у списку усіх можливих шляхів досягнення цілей буде дорівнювати сумі кількості вершин, які складають достатні умови досягнення вершини, що аналізуються. Після цього виконується аналіз реалізуємості синтезованих варіантів досягнення цілей. При наявності декількох можливих варіантів рішень (реалізуємих варіантів досягнення цілей), що відповідають одному варіанту розвитку обстановки, здійснюється вибір оптимального варіанту на основі узагальнених показників якості управління. 
5. Коригування варіантів розвитку обстанов$\kappa и$, для яких не вдалося сформувати хоча б одного варіанту рішення.

Якщо для деякого варіанту досягнення цілей не вдалося сформувати реалізуємого варіанту досягнення цілей, то виконання поставленої задачі (досягнення актуальних цілей) в сформульованому раніш вигляді виявляється неможливим. У цьому випадку повинна бути сформульована задача, яка відповідна складу та запасу ресурсів, який мається, шляхом відповідного коригування узагальненої мережної моделі.

Висновок про коректність варіанту розвитку обстановки робиться виходячи з результатів аналізу реалізуємості по ресурсам та часу складових його варіантів досягнення цілей. Тому розглянемо особливості подання варіантів досягнення цілей, які визначають послідовність аналізу його реалізуємості.

Особливості представлення варіанту досягнення цілей визначаються принципами побудови i структурою узагальненої мережної моделі і полягають в наступному [12]:

1. Він включає в себе чітко визначений комплекс дій системи (робіт) по досягненню цілей управління.

2. Мережна модель, яка відповідає варіанту досягнення цілей містить тільки вершини кон'юнктивного типу.

3. Дуги мережної моделі відображають послідовність досягнення ЦУ і відповідають одному з трьох типів робіт: дійсному, фіктивному, очікуванню.

4. Кожній дійсній роботі (відношенню дії між ЦУ) ставиться у відповідність множина ресурсів (норм витрати запасу впливів ресурсів), які можна використовувати для здійснення цієї роботи, та ча- совий інтервал, необхідний для іiі виконання. Часовий інтервал визначається ресурсами, які використовуються та початковими умовами виконання роботи і задається у вигляді точкового значення або інтервалу значень.

5. Очікування (відношення передування) процес, який вимагає витрат часу, але який не вимагає витрат ресурсів. Він характеризується часом очікування яке, як і в разі дійсної роботи, задається точковим значенням або інтервалом.

6. Фіктивна робота (відношення підпорядкування) відображає логічний зв'язок між роботами і вказує на той факт, що можливість початку однієї роботи безпосередньо залежить від завершення іншої.

7. 3 кожною роботою пов'язана деяка множина робіт, яка безпосередньо їй передує, або робіт які повинні бути виконані до іiі початку. Якщо ця множина пуста, то робота називається вихідною. Крім того, визначена множина робіт, які безпосередньо слідують за даною роботою. Якщо ця множина пуста, то робота називається завершальною. Елементи цих множин визначають послідовність виконання робіт і залежать від структури графу варіанту досягнення цілей.

8. Система має множину ресурсів $R$, за допомогою якої здійснюється виконання необхідного комплексу робіт. Модель ресурсів і апарат формалізації знань про правила їх використання викладені у другому розділі.

Приклад фрагменту графа варіанту досягнення цілей, що відображає процес вирішення на ПУ ПС, наприклад, задачі запобігання удару балістичних ракет в ході відображення масованого удару засобів повітряного нападу (ЗПН), наведено на рис. 1.

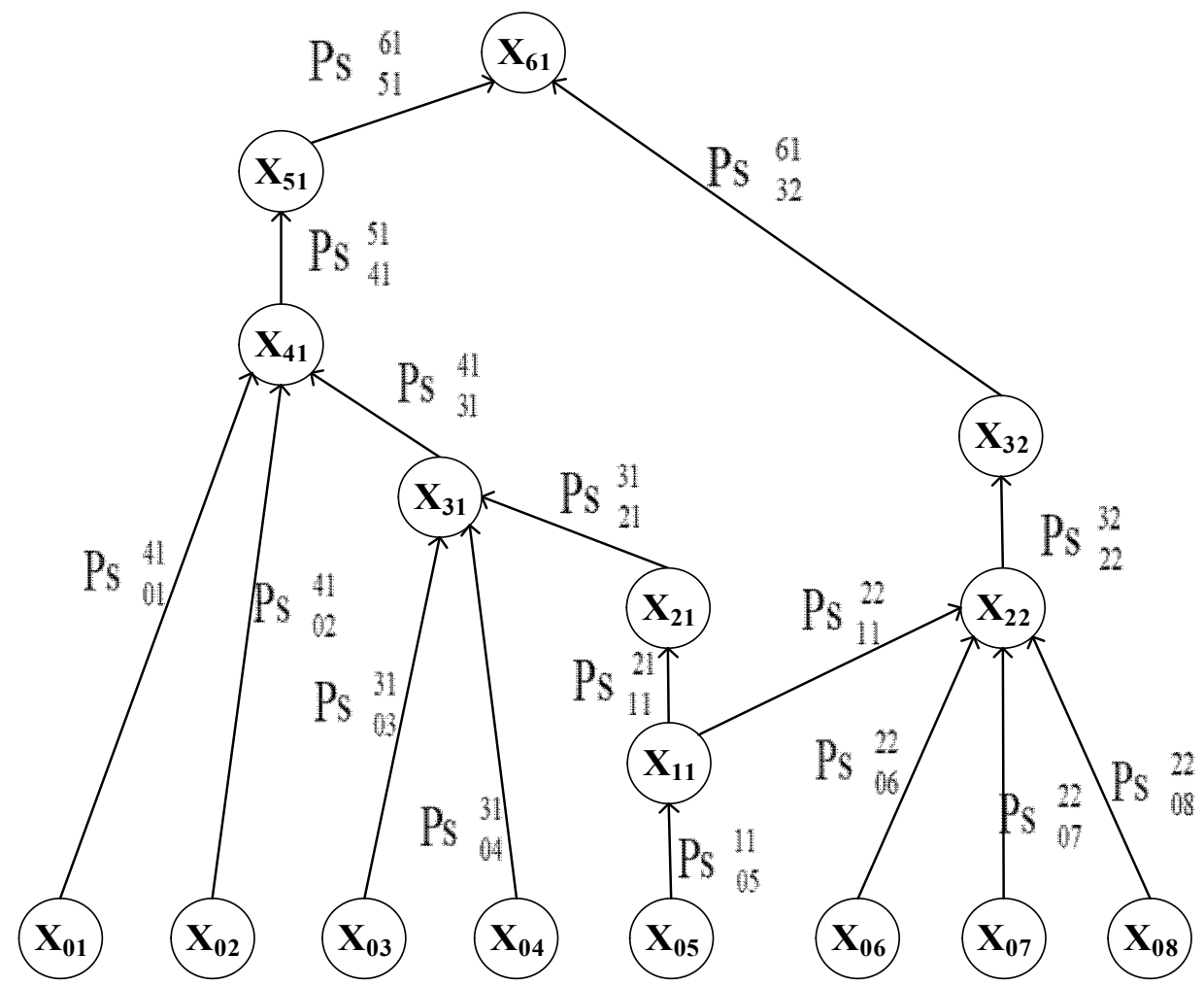

Рис. 1. Приклад фрагменту графа варіанту досягнення цілей, що відображає процес вирішення на ПУ ПС 
Розписується семантична інтерпретація вершин розглянутого прикладу фрагменту графа варіанту досягнення цілей, що відображає процес вирішення на ПУ ПС варіантів досягнення цілей.

В загальному випадку, задачу аналізу реалізуємості варіантів досягнення цілей можна сформулювати наступним чином: скласти здійсненний план реалізації варіантів досягнення цілей при відповідних обмеженнях на час досягнення поставлених цілей управління і запас ресурсів, наявних у розпорядженні.

Розрахунок часових параметрів робіт і розподіл ресурсів методами мережного планування і управління можна безпосередньо здійснювати на графі варіанту досягнення цілей, так як він повністю задовольняє вимогам до структури мережної моделі, яка досліджується методами мережного планування та управління.

Час використання ресурсу (час виконання роботи) визначається типом ресурсу, нормативними документами і набором вихідних параметрів для рішення задачі розподілу ресурсів.

Визначення часу виконання дійсних робіт і часу очікування носить явно виражений розрахунковий характер, тому їх обчислення доцільно здійснювати за допомогою спеціально розроблених розрахункових процедур.

У загальному випадку час реалізації робіт, які необхідно виконати для досягнення поставлених цілей управління, може бути задано точковим значенням або інтервалом можливих значень.

У разі якщо часи виконання всіх робіт, що належать варіанту досягнення цілей, який аналізується, задані точковими значеннями, то кожному варіанту досягнення цілей відповідає один строго визначений план реалізації. Тому для аналізу реалізуємості варіанту досягнення цілей необхідно побудувати відповідний йому план реалізації та проаналізувати його коректність 3 точки зору споживання ресурсів і часу досягнення цілі.

Побудова плану реалізації варіанту досягнення цілей полягає в розрахунку часових параметрів відповідних подій і робіт методами мережного планування та управління.

У разі якщо час використання ресурсів задається інтервалом можливих значень, то при здійсненні аналізу реалізуємості варіанту досягнення цілей виникає невизначеність в обчисленні часу початку i закінчення робіт. Внаслідок цього виникає невизначеність i в обчисленні кількості витрати запасу впливів ресурсів на кожному часовому проміжку. Тому для коректного виконання процедури розподілу ресурсів перейдемо від інтервального представлення величин до точкового.

Так як час виконання робіт, в залежності від розвитку ситуації, може приймати значення з заздалегідь заданого кінцевого набору (заданого за допомогою відповідного інтервалу), то варіанту досягнення цілей в даному випадку відповідає кінцева множини планів реалізації $\overline{P l}=\left\{P l_{1}, P l_{2}, \ldots, P l_{n}\right\}$ [11]. Причому кожен елемент цієї множини є пла- ном реалізації, в якому час виконання кожної зі складових його робіт задано конкретним числом. Множина $\overline{P l}$ може бути отримана шляхом повного перебору усіх можливих значень часів виконання робіт. У випадку, коли всі часи виконання робіт варіанту досягнення цілей задані конкретним числом, а не інтервалом, множина $\overline{P l}$ містить тільки один план реалізації. Кількість елементів множини $\overline{P l}$ можна розрахувати за такою формулою:

$$
n=\prod_{s=1}^{S} K z_{s},
$$

де $K z_{s}$ - можливих значень часу виконання $s$-ої роботи; $S$ - кількість робіт варіанту досягнення цілей, який аналізується.

Тому для того щоб визначити чи $є$ варіант досягнення цілей, який розглядається, реалізуємим за ресурсами і часу, достатньо побудувати та проаналізувати усі відповідні йому плани реалізації, які $\epsilon$ елементами множини $\overline{P l}$. Виходячи 3 цього, можна визначити порядок аналізу реалізуємості варіанту досягнення цілей по ресурсам і часу.

У загальному випадку, множину планів реалізації $\overline{P l}$, що відповідають варіанту досягнення цілей, можна розбити на три непересічні підмножини $\overline{P l}_{a}, \overline{P l}_{b}$ i $\overline{P l}_{c}$.

Підмножина $\overline{P l}_{a}$ включає в себе ті плани реалізації варіанту досягнення цілей які задовольняють обмеженням по ресурсам і часу. Плани реалізації, які не задовольняють зазначеним ресурсним обмеженням, але за допомогою процедури перерозподілу ресурсів можуть бути перетворені в реалізуємі (тобто коректні з точки зору споживання ресурсів і часу реалізації) належать множині $\overline{P l}_{b}$.

$\overline{P l}_{c}$ містить плани реалізації, які не належать множинам $\overline{P l}_{a}$ та $\overline{P l}_{b}$. Таким чином, варіант досягнення цілей $є$ реалізуємим, якщо відповідна йому множина $\overline{P l}_{c}$ не містить жодного елементу.

Виходячи $з$ порядку аналізу реалізуємості варіанту досягнення цілей, у випадку, коли часи виконання усіх складових його робіт задані тільки точковими значеннями і врахувавши особливості аналізу при інтервальному завданні часових параметрів робіт запропонований метод аналізу реалізуємості варіанту досягнення цілей по ресурсам і часу можна представити в такому вигляді:

1. Розрахунок часових параметрів робіт варіанту досягнення иілей.

На даному етапі для кожної роботи розраховується часовий інтервал іiї виконання та визначається час реалізації варіанту досягнення цілей, який розглядається. Розрахунок виконується за допомогою математичного апарату мережного планування та управління.

2. Аналіз реалізуємості варіанту досягнення иілей відповідно до заданих обмежень на час досягнення множини иільових станів. 
На даному етапі здійснюється порівняння розрахованого часу реалізації $t_{\kappa p}$ та заданого допустимого значення $t_{m p}$. Якщо $t_{\kappa p}>t_{m p}$, то розглянутий варіант не задовольняє обмеженням за часом досягнення заданих цілей управління, тобто є нереалізуємим. На цьому аналіз варіанту досягнення цілей завершується.

3. Аналіз реалізуємості варіанту досягнення ияілей відповідно до заданих ресурсних обмежень.

Фактично на цьому етапі здійснюється побудова планів реалізації, що належать множині $\overline{P l}_{a}$. Якщо дана множина містить усі плани реалізації $\left(\overline{P l}_{a}=\overline{P l}\right)$, то розглянутий варіант досягнення цілей задовольняє усім ресурсно-часовим обмеженням, тобто є реалізуємим. В іншому випадку необхідно перейти до наступного кроку.

4. Виконання прочедури перерозподілу ресурсів.

Перерозподіл ресурсів здійснюється тільки для тих планів реалізації, які не можуть бути виконані внаслідок недостатнього запасу ресурсів, тобто не належать множині $\overline{P l}_{a}$. Якщо за допомогою процедури перерозподілу ресурсів план реалізації можна перетворити до плану, що задовольняє поставленим ресурсного-часовим обмеженням, то він належить множині $\overline{P l}_{b}$, інакше розглянутий план реалізації $\epsilon$ елементом множини $\overline{P l}_{c}$. Варіант досягнення цілей $\epsilon$ реалізуємим, якщо після виконання даного етапу відповідна йому множина $\overline{P l}_{c}$ буде порожньою, в іншому випадку варіант досягнення цілей - нереалізуємий.

Далі розглянуто метод, що дозволяє синтезувати нездійсненні плани реалізації без побудови усіх елементів множини $\overline{P l}$, що істотно скорочує час, який необхідний на аналіз реалізуємості варіанту досягнення цілей.

Суть даного методу полягає в наступному. В першу чергу потрібно побудувати множину

$$
\bar{W}=\left\{\bar{W}_{1}, \ldots, \bar{W}_{n}\right\},
$$

кожен елемент якої є сукупністю робіт, які можуть виконуватися одночасно (паралельно). При цьому передбачається, що сукупність робіт може виконуватися паралельно, якщо дотримуються такі умови:

1. Роботи можуть виконуватися одночасно виходячи зі структури графу варіанту досягнення цілей. Це означає той факт, що для будь-яких двох робіт не існує такого шляху від вихідних подій до кінцевих, який містить обидві ці роботи.

2. Для виконання робіт потрібно витрата запасу впливів одного і того ж ресурсу.

3. Тимчасові інтервали виконання робіт перекриваються.

Після чого для кожного елементу множини $\bar{W}$ обчислюється необхідна кількість ресурсу на певному часовому інтервалі, i розраховане значення порівнюється з запасом впливів ресурсу, який використовується на цьому ж часовому інтервалі. Варіант досягнення цілей $є$ реалізуємим 3 точки зору споживання ресурсів, якщо для усіх типів ресурсів системи істинний вираз (5):

$$
\underset{s=1}{\forall} \bar{W}_{s} \subset \bar{W} \Rightarrow\left\{\begin{array}{l}
\sum_{j=1}^{k_{s}} \sum_{q=1}^{Q} \max _{t=t o_{s}^{1}}^{2} H \beta\left(R_{i}, t\right)_{q j} \leq \\
\operatorname{tos}_{s}^{2} \\
\leq \min _{t=t o_{s}^{1}}^{1} V\left(R_{i}, t\right)-\lambda\left(R_{i}\right)
\end{array}\right\},
$$

де $k_{s}$ - кількість робіт, що належать підмножині $\bar{W}_{s} ; Q-$ кількість норм витрати запасу впливів $i$ го ресурсу; $T o_{s}^{*}=\left[t o_{s}^{1}, t o_{s}^{2}\right]$ - часовий інтервал, на якому можливе одночасне виконання робіт, які належать підмножині $\bar{W}_{s} ; H s\left(R_{i}, t\right)_{q j}-q$-та норма витрати запасу впливів $i$-го ресурсу $j$-ою роботою в момент часу $t ; V\left(R_{i}, t\right)$ - запас впливів $R_{i}$ ресурсу в момент часу $t ; \lambda\left(R_{i}\right)$ - мінімальний запас впливів ресурсу, який не підлягає витрачанню (визначається командиром).

Якщо вираз (5) не виконується, то виділяються сукупності робіт $\bar{W}_{r} \subset \bar{W}$, для виконання яких потрібно більше ресурсу, ніж існує його в наявності. Після цього синтезуються плани реалізації, що містять на встановлених часових проміжках отримані сукупності робіт $\bar{W}_{r}$ (процедура синтезу буде описана далі). В результаті цього буде сформована множина планів реалізації варіанту досягнення цілей, які не задовольняють поставленим обмеженням на використання ресурсів системи та вимагають виконання для них процедури перерозподілу ресурсів.

\section{Висновки і напрямки подальших досліджень}

Таким чином, при синтезі на ПУ ПС варіантів дій підпорядкованих сил та засобів необхідно враховувати не тільки можливість досягнення поставлених цілей управління виходячи зі структури узагальненої мережної моделі, але й існуючі обмеження на кількість ресурсів, які використовуються, та час виконання рзавдання. Тому необхідна розробка методу, який дозволяє не тільки побудувати можливі шляхи досягнення цілей, а й здійснити їх аналіз реалізуємості з урахуванням існуючих обмежень.

У загальному випадку, виходячи 3 аналізу інформації, яка характеризує обстановку, що склалася і використовується особами бойової обслуги ПУ ПС в процесі вироблення рішень неможливо однозначно визначити, як надалі буде розвиватися ситуація. Це обумовлено як цілеспрямованим протидією противника, так і наявністю величезної кількості зовнішніх випадкових факторів. Тому кожній ситуації відповідає деяка множина варіантів розвитку обстановки, які характеризують різні шляхи досягнення актуальних цілей, обумовлені наявністю дій з невизначеним результатом. Варіант розвитку обстановки вважається коректним в даній ситуації, якщо для нього можна сформувати хоча б один варіант досягнення цілей, що реалізується за ресурсами і часом. 
Розроблений метод синтезу можливих варіантів рішень дозволяє сформувати в реальному масштабі часу для кожного варіанту розвитку обстановки множину реалізуємих варіантів досягнення цілей (варіантів розподілу ресурсів), якщо вони існують. При цьому враховується той факт, що вихідні дані для розрахунків можуть бути задані як у вигляді точкових значень, так й у вигляді інтервалів можливих значень.
Якщо в процесі вироблення рішень для певного виду розвитку обстановки не вдалося сформувати жодного реалізуємого варіанту досягнення цілей, то досягнення поставлених цілей управління в даній ситуації неможливо.

В цьому випадку варіант розвитку обстановки потребує коригування.

Напрямком подальших досліджень є розробка методу коригування варіанту розвитку обстановки.

\title{
СПИСОК ЛІТЕРАТУРИ
}

1. Васюта К. С. Розробка моделі використання ресурсів у відкритій експертній системі пункту управління Повітряних Сил / К. С. Васюта, Д. А. Чопенко // Системи управління, навігації та зв'язку. — 2019. — № 6 (58). — С. 9-14.

2. Васюта К. С. Ресурсно-часові вимоги, яким повинні задовольняти синтезовані варіанти досягнення множини цільових станів при формалізації задач управління / К. С. Васюта, Д. А. Чопенко // Новітні технології - для захисту повітряного простору : XVI Міжнар. наук. конф. 15-16 квіт. 2020 р. : тези допов. - Харків, 2020. - С. 36-37.

3. Василенко Д. Е. Метод формализации знании в открытой экспертной системе реального времени в автоматизированных системах управления воздушным движением / Д. Е. Василенко, Д. Н. Обидин, П. Г. Бердник, В. Н. Руденко // Системи озброєння і військова техніка. — 2016. — № 3 (47). — С. 112-117.

4. Wang J. Q. Three-dimensional gantt chart based resource-constrained multiple projects scheduling and critical chain identification / J. Q. Wang, S. F. Zhang, J. Chen, S. Wang, Y. F. Zhang. - 2011 IEEE 18th International Conference on Industrial Engineering and Engineering Management. - 2011. https://doi.org/10.1109/icieem.2011.6035465.

5. Habibi F. Resource-constrained project scheduling problem: Review of past and recent developments / F. Habibi, F. Barzinpour, S. J. Sadjadi // Journal of Project Management. - 2018. - No. 3. - P. 55-88. https://doi.org/10.5267/j.jpm. 2018.1.005.

6. Карайман О. О. Тривимірна діаграма Ганта як графічне вирішення проблеми планування проектів 3 обмеженими ресурсами / О. О. Карайман, А. О. Афонін // Наукові записки НаУКМА. Комп’ютерні науки. -2019. - Том 2. С. 50-55. DOI: $10.18523 / 2617-3808.2019 .2 .50-55$.

7. Методи сучасної теорії управління: підручник / А.П. Ладанюк, Н.М. Луцька, В.Д. Кишенько, Л.О. Власенко, В.В. Іващук. - Київ : Видавництво Ліра-К, 2019. - 368.

8. Загорко О. М. Елементи дослідження складних систем військового призначення / О. М. Загорко, С. П. Мосов, А. І. Сбітнєв, П. І. Стужук. - К.: НАУО, 2005. - 99 с.

9. Субботін С. О. Подання й обробка знань у системах штучного інтелекту та підтримки рішень: навчальний посібник / С. О. Суботін. - Запоріжжя: ЗНТУ, 2008. - 341 с.

10. Amin Salih Mohammed, Saravana Balaji B., Saleem Basha M S, Asha P N and Venkatachalam K (2020), FCO — Fuzzy constraints applied Cluster Optimization technique for Wireless AdHoc Networks, Computer Communications, Volume 154, Pages 501-508, DOI: https://doi.org/10.1016/j.comcom.2020.02.079.

11. Маценко В. Г. Математичне моделювання: навчальний посібник / В. Г. Маценко. — Чернівці: Чернівецький національний університет, 2014. - 519 с.

12. Лістровий С. В. Теорія автоматичного керування, штучний інтелект і автоматизація процесу прийняття рішення : навчальний посібник / С. В. Лістровий, М. А. Мірошник, Л. А. Клименко. — Харків: УкрДУЗТ, 2019. — 120 с.

Received (Надійшла) 30.10.2020

Accepted for publication (Прийнята до друку) 27.01.2021

\author{
Method for synthesis of solution variants in the open expert system \\ of the air force control point, taking into account the resource-time limits
}

Kostiantyn Vasiuta, Dmytro Chopenko, Nataliia Harmash

Abstract. The subject matter in the article is options for achieving solutions taking into account the specified resource-time constraints in the open expert system of the Air Force control center. The goal is to develop a method for synthesizing solutions in an open expert system of the Air Force control center, taking into account resource-time constraints. The analysis of the possibility of achieving a set of target states in terms of resources and time on the strip Gantt chart and methods of network planning and management is carried out. The following results were obtained. The stages of synthesis of possible options, features of presentation of options for achieving goals are described. The task of analyzing the feasibility of options for achieving goals is formulated. The given example of a fragment of the graph of the option for achieving goals, which reflects the process of solving the problem in an open expert system at the Air Force control point. A method for analyzing the feasibility of the option to achieve goals in terms of resources and time is described. The construction of a plan for the implementation of the option to achieve goals is proposed. A method is considered that allows one to synthesize impracticable implementation plans. Conclusions. The developed method for the synthesis of possible solutions makes it possible to form, in real time, for each scenario of the situation development, a set of realizable options for achieving goals (resource allocation options), if they exist. This takes into account the fact that the initial data for calculations can be specified both in the form of point values and in the form of intervals of possible values. The direction of further research is the development of a method for correcting the variant of the development of the situation if, in the process of making decisions for a certain type of development of the situation, it was not possible to form a single realized variant of achieving the goals.

Keywords: control point, open expert system, resource-time constraints, method of network planning and management, formalization, structure of target settings. 